\title{
Peluang dan Tantangan : Penggunaan Media Digital di Kalangan Perempuan Jatinangor
}

\author{
Eni Maryani dan Kismiyati El Karimah \\ email: eni.maryani@unpad.ac.id, kismiyati@unpad.ac.id \\ Universitas Padjadjaran, Jl. Raya Bandung Sumedang Km 21, Sumedang, Indonesia
}

Submitted: 05 December 2019 Revised: 11 December 2019 Accepted: 19 December 2019

\begin{abstract}
Abstrak
Membahas penggunaan media digital di berbagai konteks masyarakat merupakan kebutuhan yang tidak dapat dihindari karena sebagai teknologi penggunaan media memiliki dampak baik positif maupun negative. Tulisan ini akan mengangkat isu tentang penggunaan media oleh kalangan perempuan di sebuah kawasan yang dikenal dengan nama Jatinangor. Sebagai sebuah kawasan pendidikan di sisi Timur kota Bandung dan termasuk wilayah Kabupaten Sumedang Jatinangor memiliki perkembangan sosial ekonomi yang cukup dinamis. Sebuah wilayah pedesaan yang kemudian mengalami perubahan yang cukup signifikan dengan banyaknya pendatang mahasiswa di wilayah tersebut. Berkembangnya infrastruktur teknologi komunikasi akhirnya juga berimplikasi pada berkembangnya penggunaan media digital di kalangan perempuan di wilalah Jatinangor. Menggunakan pendekatan kualitatif dengan teknik pengumpulan data wawancara mendalam, observasi dan studi literatur, penelitian ini berupaya mengungkap implikasi penggunaan media digital dikalangan perempuan Jatinangor terkait dengan nilai-nilai patriarki yang umumnya mempengaruhi pemikiran, sikap dan tindakan kalangan perempuan. Hasil penelitian menunjukkan terdapat peluang bagi perempuan pengguna media digital untuk mengatasi beberapa hambatan budaya dalam mendapatkan ruang komunikasi bagi diri mereka khususnya di wilayah publik. Akan tetapi penggunaan media digital yang mereka lakukan juga memberi tantangan pada mereka untuk mengembangkan sikap selektif, kritis dan rasional yang secara budaya umumnya tidak ditanamkan pada mereka. Jika tidak maka penggunaan media digital justru dapat menjadikan mereka sebagai objek atau sasaran dari berbagai kegiatan komunikasi yang bersifat komersial maupun kriminal.
\end{abstract}

Kata kunci: gender, media digital, patriarki, perempuan

\section{Challenges and Opportunities: The Use of Digital Media By Woman in Jatinangor}

\begin{abstract}
The discussion of digital media usage in various societal contexts is a necessity that cannot be avoided since it has both positive and negative impacts. This article will raise the issue of digital media usage by women in Jatinangor. Jatinangor is an educational area on the east side of Bandung and including the Sumedang Regency area. Jatinangor has quite dynamic social economic development and has experienced a significant change with the number of student arrivals in the area. The development of communication technology infrastructure also has implications for the growing use of digital media among women in the Jatinangor area. Using a qualitative approach with in-depth interviews observation and literature studies, this study seeks to uncover the implications of digital media among Jatinangor women related to patriarchal values that generally affect women's thoughts, attitudes and actions. The results of the study show that there are opportunities for women who use digital media to overcome some cultural barriers in gaining communication space for themselves, especially in the public domain. However, the use of digital media also challenges these women to develop selective, critical and rational attitudes that are not familiar for them. The lack of these attitudes can actually make these women objects or targets of various commercial and criminal communication activities.
\end{abstract}

Keywords: gender, digital media, patriarchy, women 
PENDAHULUAN

Berkembangnya

aktivitas

masyarakat perkotaan menghasilkan perluasan ruang berbagai kegiatan di wilayah sekitarnya. Hal ini terjadi hampir di semua kota besar di Indonesia seperti halnya Kota Jakarta dan Bandung. Walaupun Jakarta dan Bandung merupakan kota yang skalanya jauh berbeda akan tetapi pola perkembangannya relatif sama. Jakarta sebagai kota besar melahirkan daerah penyangga disekitarnya yaitu Bogor, Depok, Tangerang dan Bekasi yang kemudian menjadi wilayah yang saling terkait sehingga dikenal dengan istilah Jabodetabek. Sementara itu pemerintah Jawa Barat juga mengembangkan Bandung menjadi Bandung Metropolitan Area (BMA) dengan mengembangkan daerah sekitarnya baik di Barat, Utara, Timur, maupun Selatan (Perdana, 2019)

Walaupun tidak sebesar Depok dan Bogor daerah Cimahi dan Padalarang telah menjadi daerah penyangga Bandung di sisi Barat. Sementara di bagian Utara yang menjadi penyangga Bandung adalah daerah Lembang, khususnya sebagai tujuan wisata yang menyediakan udara sejuk dan beragam wisata kuliner yang selalu padat di setiap akhir minggu atau hari libur. Di bagian Selatan Bandung berkembangnya daerah yang menjadi pusat perkembangan industri berupa pabrik-pabrik diantaranya daerah Banjaran, Soreang dan sekitarnya. Di sisi selatan juga terdapat daerah yang menjadi tujuan wisata yaitu Pangalengan dan Ciwidey. Perluasan wilayah yang relatif penting adalah perluasan ke sisi Timur kota Bandung. Di wilayah ini dikembangkan Kawasan Pendidikan Jatinangor yang memiliki beberapa
Perguruan Tinggi seperti Universitas Padjadjaran (Unpad), Institut Teknologi Bandung (ITB), Institut Pemerintahan Dalam Negeri (IPDN), dan Institut Koperasi Indonesia (Ikopin). Kawasan Pendidikan Jatinangor ditetapkan tahun 1987 melalui Surat Keputusan Gubernur Jabar No. 593/3590/1987, sejalan dengan rencana pembangunan Bandung Metropolitan Area (BMA) dan Megapolitan Jakarta Bandung (Pemerintah Provinsi Jawa Barat, 2018)

Pada awalnya Jatinangor adalah nama blok perkebunan yang terletak di kaki Gunung Manglayang dan masuk dalam wilayah Kecamatan Cikeruh akan tetapi sejak tahun 2000 Jatinangor menjadi nama Kecamatan menggantikan nama Cikeruh. Kecamatan Jatinangor meliputi 12 desa yang terdiri dari Desa-Desa Cilayung, Cipacing, Sayang, Mekargalih, Cintamulya, Cisempur, Jatimukti, Jatiroke, Hegarmanah, Cikeruh, Cibeusi dan Cileles yang termasuk ke dalam wilayah Kabupaten Sumedang. Kawasan Jatinangor juga mengalami perubahan ekonomi yang sangat berkembang sepertin kos-kosan, rumah kontrkan, apartemen dan berbagai bentuk café, restoran, tempat hiburan dan lain-lain ( Pemerintah Provinsi Jawa Barat, 2018)

Kedatangan ribuan mahasiswa setiap tahunnya menjadikan kawasan Jatinangor mengalami perubahan secara fisik yang signifikan. Saat ini di kawasan Jatinangor bermunculan beragam aktivitas ekonomi, khususnya terkait dengan kebutuhan mahasiswa dari berbagai kalangan dan dari berbagai daerah. Aktivitas ekonomi tersebut mencakup perkembangan binis terkait dengan penyediaan fasilitas penginapan, layanan makanan, dan berbagai layanan yang 
terkait dengan kepentingan pendidikan atau gaya hidup kalangan mahasiswa dari berbagai kalangan. Perkembangan yang terjadi secara signifikan juga mendorong meningkatnya kualitas dan kuantitas akses internet sejalan dengan upaya untuk memenuhi kebutuhan mahasiswa.

Meningkatnya akses masyarakat terhadap internet pada akhirnya akan memiliki dampak pada kehidupan masyarakatnya. Penelitian Kominfo tentang penggunaan Teknologi Komunikasi dan Informasi (TIK) serta implikasinya terhadap aspek sosial budaya di masyarakat baik perkotaan maupun pedesaan melihat tiga hal yaitu terkait kesejahteraan sosial (individu \& keluarga); Ikatan sosial (individu \& keluarga); dan Sosial budaya (individu \& keluarga). Berdasarkan uji path kualitas pelayanan (standardized solution), variabel indikator yang paling berpengaruh pada variabel penggunaan perangkat TIK adalah kesejahteraan individu dan kondisi sosial budaya individu maupun keluarga (Kominfo, 2017). Melihat data tersebut terlihat bahwa teknologi komunikasi selain berdampak pada aspek-aspek sosial dan budaya juga berdampak pada manusia sebagai individu. Merujuk pada data tersebut maka perlu dipertimbangkan bahwa pada dasarnya terkait dengan pembangunan aspek manusia menjadi salah satu aspek penting diantara dimensidimensi lain dalam pembangunan seperti sosial budaya, politik, ekonomomi, dan lingkungan (Malikhao, 2014).

Merujuk pada dampak penggunaan teknologi informasi komunikasi atau media digital (media yang berbasis internet) terhadap kehidupan sosial seperti yang diungkapkan oleh penelitian (Kominfo, 2017) maka melihat perubahan sosial yang terjadi di Jatinangor menjadi penting. Perubahan yang terjadi di Jatinangor melahirkan asumsi bahwa segala perubahan yang terjadi juga akan berimplikasi pada penduduk setempat (bukan mahasiswa pendatang) termasuk kaum perempuan di Jatinangor. Terkait dengan akses masyarakat Jatinangor yang cukup meningkat maka menjadi penting untuk melihat dampaknya pada kalangan perempuan di Jatinangor terutama kaum ibu. Hal ini menarik untuk dilihat karena pada dasarnya teknologi selalu bermata dua dan terkait dengan perempuan teknologi tidak selalu kemudian berdampak positif. Permasalahan terkait teknologi dan perempuan pada akhirnya terkait dengan relasi kekuasaan. Teknologi dapat menciptakan monopoli pengetahuan oleh kelompok dominan di dalam masyarakat dan mengucilkan kelompok marjinal misalnya kelompok perempuan dan anak-anak. Konspirasi seperti ini mungkin terjadi terutama terkait dengn teknologi digital - berdasarkan pandangan Giddens selalu berbentuk expert system yang hanya dapat dipahami oleh kelompok ahli - yang dalam banyak kasus di dominasi laki-laki (Saputra, 2001).

Selain itu gambaran di atas, teknologi digital juga dapat menjadi tempat terjadinya kekerasan terhadap perempuan namun jarang dilaporkan. Salah satu riset di Malayasia mengungkapkan tentang fenomena cyberstalking terkait dengan perempuan. Menurut Association for Progressive Communications (APC), cyberstalking atau tindakan menguntit secara Online mencakup tindakan-tindakan (dilakukan berulang kali) mengirimkan ancaman atau tuduhan palsu melalui email atau telepon seluler, membuat posting yang 
mengancam atau palsu di situs web, mencuri identitas atau data seseorang, memata-matai seseorang dan memantau penggunaan komputer atau internet seseorang. Studi yang meneliti tentang prevalensi, persepsi, dan pelaporan cyberstalking di kalangan mahasiswa tersebut mengungkapkan bahwa perempuan mengalami prevalensi cyberstalking yang lebih tinggi daripada pria, menganggap cyberstalking lebih berbahaya, akan tetapi dianggap kurang serius ketika melaporkan insiden cyberstalking (Gan, 2017). Kekerasan atu bullying juga terjadi terjadi kalangan mahasiswa Indonesia. Diketahui pada tahun 2006, ada 29 kasus kekerasan fisik, 67 kasus kekerasan seksual, dan 96 ases kekerasan psikis di perguruan tinggi (Khadijah, 2018). Tindak kekerasan dalam dunia nyata dapat terjadi lebih parah dan sering di media sosial. Oleh karena itu berdasarkan beberapa hasil hasil riset terkait implikasi penggunaan internet terhadap tindakan kekerasan maka pertimbangan keamanan dan privasi merupakan tantangan yang harus dihadapi di masa depan dan dibutuhkan kebijakan untuk mengatasinya (Maple, 2017).

Penggunaan media digital oleh perempuan di kawasan Jatinangor juga menjadi penting apabila kita merujuk pada riset yang dilakukan Kominfo. Berdasarkan riset Kominfo pada 9.419 responden di wilayah perkotaan maupun pedesaan ditemukan bahwa banyaknya perempuan yang terakses pada internet antara laki-laki dan perempuan relatif tidak berbeda yaitu 48, $76 \%$ (Kominfo, 2017). Artinya teknologi punya peluang memberi akses yang relatif sama pada perempuan dan laki-laki.
Berdasarkan data di atas maka terdapat salah satu bukti yang mengungkap bahwa kecanggihan teknologi yang semakin memudahkan penggunaan (user friendly) memberi peluang perempuan untuk mengakses teknologi melalui penggunaan beragam media. Ketidakmampuan perempuan dalam halhal terkait dengan penggunaan teknologi tidak lagi terbukti, karena teknologi semakin mudah digunakan termasuk oleh kalangan perempuan, Semakin terbukanya akses perempuan terhadap media memberi kesempatan perempuan untuk meningkatkan pengetahuan dan partisipasinya di berbagai bidang kehidupan sosial.

Di dalam budaya masyarakat Sunda yang mengandung nilai-nilai patriarki dikenal ungkapan yang menyatakan bahwa perempuan itu 'pondok lengkah' yang secara harafiah artinya 'langkahnya pendek'. Artinya dalam masyarakat Sunda perempuan dimaknai memiliki kesempatan beraktivitas yang terbatas atau jangkauan perempuan terhadap lingkungan sosialnya sangat terbatas. Kemudian ada juga ungkapan yang menggambarkan peran perempuan yang dikaitkan dengan aktivitas terkait dengan 'dapur, sumur dan kasur'. Artinya aktivitas perempuan khsususnya yang sudah menikah hanya berkutat di wilayah domestik atau di dalam rumah.

Selain itu kita juga mengenal apa yang dikenal dengan istilah feminin (femininity) dan maskulin (masculinity) seperti krteria-kriteria atau konsep-konsep berikut. Maskulin adalah sikap-sikap atau nilai yang diantaranya adalah sikap tegas, kompetitif, rasional, kuat, beorientasi pada diri sendiri. Sementara nilai-nilai feminin diantaranya ragu-ragu, peduli, emosional, 
lembut dan beorientasi pada kepentingan orang lain (keluarga seperti orang tua, suami, anak). Padahal baik perempuan maupun laki-laki dapat memiliki sifat feminin maupun maskulin. Kedua sifat tersebut dapat dipertukarkan bukan sesuatu yang secara alamiah melekat pada diri laki-laki atau perempuan (Fakih, 2016)

Penelitian terkait dengan isu maskulin dan feminin adalah penelitian tentang kasus insiden Dickwolves dari Penny Arcade.com. Penelitian ini membahas masalah hipermaskulinitas dan seksisme dalam komunitas game dan bagaimana diskursus hypermasculine mendorong keistimewaan maskulinitas terhadap feminitas dan menghambat keterlibatan perempuan dalam diskursus gender dikomunitasnya (Salter \& Blodgett, 2012). Akan tetapi media digital juga dapat mendukung gerakan perempuan dalam melawan tindak kekerasan terhadap perempuan seperti riset yang dilakukan terkait digital activism tentang kekerasan terhadap perempuan. Penelitian yang mengangkat penyebarluasan film "16 Days of Activism' mengungkapkan bahwa media sosial dalam hal ini You Tube memiliki daya tarik bagi khalayak untuk menerima dan lebih memahami isu kekerasan terhadap perempuan (Maryani \& Astari, 2019). Selain dapat memperluas advokasi dengan kemasan yang menarik, media sosial juga dapat memperkenalkan ide-ide yang dianggap baru oleh masyarakat misalnya terkait dengan peran laki-laki atau kepedulian laki-laki terhadap isu-isu yang awalnya dilekatkan pada perempuan seperti media sosial Aliansi Laki-laki baru dan Ayah ASI (Rahmawan, 2018; Maryani \& Zuriyyatina, 201)

Mengapa pembahasan tentang kaum perempuan berkaitan dengan penggunaan teknologi khususnya media digital di kalangan perempuan menjadi penting? Merujuk pada berbagai penelitian yang telah dilakukan. Berangkat dari pengamatan terhadap penggunaan media digital di kalangan ibu-ibu di kawasan Jatinangor tulisan ini berusaha melihat peluang serta tantangan dengan teraksesnya perempuan di Jatinangor terhadap media digital. Bagaimana implikasi penggunaan media digital yang mereka lakukan terhadap diri mereka dan interaksi mereka.

Penelitian ini mengasumsikan bahwa perubahan yang terjadi di sekitar Jatinangor memiliki implikasi pada penggunaan media digital di kalangan perempuan daerah tersebut. Akan tetapi nilai-nilai budaya masyarakat Jatinangor khsususnya budaya masyarakat Sunda yang juga masih bersifat patriarki juga mempengaruhi penggunaan media digital oleh kaum perempuan serta implikasinya. Merujuk pada asumsi tersebut maka penelitian ini mencoba mengungkap bagaimana pengguna media digital di kalangan perempuan Jatinangor baik dari segi manfaat maupun tantangannya terutama dikaitkan dengan nilai-nilai budaya yang mengkostruksi peran sosial perempuan di masyarakat.

\section{METODE PENELITIAN}

Penelitian ini merupakan penelitian yang menggunakan pendekatan kualitatif terhadap kasus penggunaan media digital oleh kalangan perempuan di Jatinangor. Jatinangor adalah sebuah daerah pedesaan yang mengalami banyak perubahan ketika berkembang menjadi kawasan Pendidikan Tinggi di sebelah timur kota Bandung. Terkait itu peneliti mengasumsikan terdapat perubahan yang cukup signifikan 
dari kalangan perempuan Jatinangor yang secara tidak langsung mengalami dampak berbagai perubahan yang terjadi disekitarnya.

Secara singkat dapat dinyatakan bahwa penelitian kualitatif adalah penelitian yang bersifat interpretif dan menggunakan penafsiran dalam menelaah masalah penelitian. Sebagai sebuah penelitian kualitatif yang menggunakan studi kasus sebagai metodenya maka penelitian ini menggunakan beragam sumber data untuk memahami kasus yang diteliti. Untuk itu dalam studi seperti ini umumnya digunakan beberapa teknik pengumpulan data (Cresswell, 2007). Penggunaan teknik pengumpulan data dilakukan untuk menghasilkan data yang lebih komprehensif dari berbagai sumber dan jenis data. Hal itu dilakukan agar peneliti mendapat pemahaman yang holistik terkait dengan realitas yang diteliti (Mulyana, 2018). Penelitian ini juga melalukan triangulasi metodologi dalam proses analisi data. Triangulasi metodologi dalam penelitian ini dilakukan untuk mengecek keabsahan data dengan melihat konsistensi data yang diperoleh berdasarkan wawancara mendalam, observasi dan studi literatur (Miles \&Huberman, 1984).

Merujuk pada kebutuhan data dari beragam sumber maka teknik pengumpulan data yang digunakan dalam penelitian ini adalah wawancara mendalam, observasi dan studi literatur. Narasumber utama yang dirujuk dalam wawancara mendalam adalah perempuan di wilayah Jatinangor yang menggunakan media digital. Wawancara dilakukan terhadap 12 perempuan di Jatinangor yang terdiri dari beragam usia dan memiliki status menikah maupun tidak. Selain itu wawancara juga dilakukan terhadap pakar gender, media digital dan tokoh masyarakat setempat. Observasi dilakukan terhadap perkembangan penggunaan media digital di kalangan perempuan Jatinangor. Selanjutnya untuk melengkapi beberapa data sekunder terkait fenomena yang diteliti serta konsep dan teori yang dirujuk dalam penelitian ini maka dilakukan pengumpulan data melalui studi literatur.

\section{HASIL DAN PEMBAHASAN}

Berdasarkan perolehan data terkait dengan penggunaan media digital khususnya telepon gemgam atau handphone maka diperoleh beberapa gambaran penting terkait penggunaan, manfaat dan beberapa implikasi yang tidak diharapkan dialami oleh perempuanperempuan tersebut. Untuk memahami fenomena yang terjadi dan analisis yang dilakukan maka pada bagian selanjutnya akan dipaparkan isu-isu terkait penggunaan, manfaat penggunaan media digital dan tantangan yang dihadapi kalangan perempuan pengguna media digital tersebut.

Penggunaan internet atau media digital di kalangan perempuan di Jatinangor berkembang dengan mudahnya melalui penggunaan telepon seluler. Beberapa perempuan di Jatinangor mengaku bahwa pengunaan media digital khususnya media sosial dilakukan melalui handphone yang mereka miliki. Salah seorang informan yang mengaku tidak mengakses media sosial karena telepon seluler yang dimiliki hanya sebatas dapat digunakan untuk menelepon dan mengirim pesan singkat (short mesenger service atau SMS). Adapun media sosial yang digunakan adalah whatsApp, facebook, 
Instagram, dan line. Selain itu media seperti YouTube, Google, dan website juga kerapkali mereka akses atau gunakan.
Secara terinci gambaran penggunaan media digital para informan dapat dilihat dalam tabel berikut.

Tabel 1. Penggunaan Media Digital Para Informan Penelitian

\begin{tabular}{|c|c|c|c|c|c|c|c|}
\hline \multirow{2}{*}{ Informan } & \multicolumn{7}{|c|}{ Penggunaan Media Digital } \\
\hline & Facebook & WhatsApp & YouTube & Line & Instagram & Google & SMS \\
\hline 1 & & $\mathrm{~V}$ & & & & & \\
\hline 2 & & $\mathrm{v}$ & & $\mathrm{v}$ & $\mathrm{V}$ & & $\mathrm{V}$ \\
\hline 3 & & $\mathrm{~V}$ & & $\mathrm{~V}$ & $\mathrm{~V}$ & & \\
\hline 4 & $\mathrm{~V}$ & $\mathrm{~V}$ & $\mathrm{~V}$ & & & $\mathrm{v}$ & \\
\hline 5 & $\mathrm{~V}$ & & & & & & \\
\hline 6 & $\mathrm{v}$ & $\mathrm{V}$ & & & & & \\
\hline 7 & & & $\mathrm{~V}$ & & & $\mathrm{~V}$ & \\
\hline 8 & & & $\mathrm{v}$ & & & $\mathrm{V}$ & \\
\hline 9 & & & & & & & $\mathrm{~V}$ \\
\hline 10 & & $\mathrm{~V}$ & & $\mathrm{~V}$ & & & $\mathrm{~V}$ \\
\hline 11 & $\mathrm{v}$ & $\mathrm{v}$ & & & $\mathrm{v}$ & & \\
\hline 12 & & & & $\mathrm{~V}$ & $\mathrm{~V}$ & & $\mathrm{~V}$ \\
\hline
\end{tabular}

Sumber : Hasil pengolahan data

Berdasarkan data yang dikumpulkan dari para perempuan di Jatinangor mengenai penggunaan media baru atau media digital ditemukan bahwa terdapat variasi pola penggunaan media. Gambaran penggunaan teknologi dalam hal ini telepon seluler diungkapkan oleh salah seorang perempuan di Jatinangor yang menyatakan bahwa dia dan temantemannya biasanya menggunakan Line, Whatsapp, dan Instagram. Setiap media yang mereka gunakan memiliki tujuan yang berbeda sejalan dengan fungsi-fungsi yang disediakan masing-masing aplikasi seperti dikemukakan dalam pernyataan berikut

"Kalau Line, ibu suka memakai aplikasi ini buat komunikasi kepada teman kerja, anak-anak, dan suami ibu. Komunikasi dalam aplikasi Line, ibu lebih menggunakannya untuk individu ke individu lain hehe.
Sekarang Whatsapp yaa.. kalau Whatsapp lebih ke persoalan bisnis, Group Chat, dll. Yaa pada intinya kalau Whatsapp itu dipakai untuk komunikasi secara formal. Terakhir Instagram bukan sih haha oh iyaa instagram, Nah kalau instagram saya lebih ke berbagi video di instastory, berbisnis, jual-beli, onlineshop dll. Itu deh kayanya yang ibu tahu hehe .....kalau website.. ah paling ibu mah hanya mengunjungi website brand fashion aja de hahaha (Hasil wawancara dengan informan 3).

Berdasarkan ungkapan informan di atas maka dapat diketahui bahwa terdapat penggunaan telepon seluler untuk melakukan komunikasi keluarga baik dengan suami maupun anak-anak mereka. Selain itu telepon seluler juga dapat memfasilitasi komunikasi kaum ibu terkait dengan pekerjaan maupun pergaulan mereka. Pengakuan relatif serupa juga dikemukakan ibu-ibu lain terutama terkait 
dengan pencarian informasi untuk mengembangkan wawasan atau pengetahuan dan juga aktivitas mereka terkait gaya hidup, pendidikan, ekonomi dan bisnis, serta hiburan. Melalui penggunaan beragam media tersebut maka pemikiran yang mengaitkan batasan perempuan dengan ungkapan dalam bahasa Sunda yaitu 'pondok lengkah' (langkahnya pendek) atau perempuan dianggap hanya beraktivitas seputar 'dapur, sumur dan kasur' dapat mengalami perubahan.

Gaya Hidup. Selain dapat memfasilitasi komunikasi kaum perempuan dengan keluarga dan lingkungannya, penggunaan media digital juga menghasilkan kebiasaan baru di kalangan perempuan di Jatinangor yaitu kebiasaan mengunggah foto-foto mereka di media sosial. Kebiasaan baru tersebut dapat terbentuk karena berkembangnya aplikasi-aplikasi yang mudah digunakan dan dikhususkan untuk mengunggah foto-foto seperti dalam media sosial Instagram. Hal tersebut terungkap dalam pernyataan berikut :

"Instagram, Kalo WhatsApp buat komunikasi sama keluarga termasuk anak-anak, kadang juga kerjaan suka pake whatsApp. Kalo Line dipake buat komunikasi sama keluarga juga ditambah buat nyari informasi juga. Instagram dipake buat nge post foto-foto (Hasil wawancara dengan informan 2).

Berkembangnya aktivitas mengunggah foto melalui media digital umumnya tidak disertai adanya kesadaran untuk menjaga data-data yang bersifat pribadi. Mereka kurang menyadari apabila foto-foto yang mereka unggah dapat dimanfaatkan oleh orang lain untuk tujuan yang tidak baik. Ketika ditanyakan foto- foto apa yang mereka unggah di Instagram, beberapa informan menjawab foto-foto yang diunggah adalah foto-foto berbagai kegiatan mereka khususnya dalam acara-acara khusus, tempat-tempat wisata atau ada ditempat-tempat yang bagus atau menarik. Salah seorang informan menyatakan bahwa 'sekarang kan kalau kita cari tempat makan juga suka cari tempat bagus untuk foto-foto, supaya bisa foto-foto kan terus di upload deh. Supaya temen-temen kita juga tahu kalau ada tempat yang bagus buat foto-foto" (wawancara dengan informan 3 dan 11).

Penggunaan media digital juga menghasilkan kebiasaan baru dikalangan perempuan penggunanya. Berdasarkan perolehan data dapat dimakna bahwa dikalangan mereka berkembang juga kebiasaan untuk menambah pengetahuan dan wawasan mereka tentang gaya pakaian. Hal ini dapat diketahui dari salah satu ungkapan perempuan yang diwawancara yang mengungkapkan pernyataan berikut : "Terus ada fashion (di media digital), jadi kita bisa tahu model-model fashion terbaru” (Hasil wawancara dengan informan 2).

Sebagian dari perempuan yang menjadi informan juga mengungkapkan bahwa mereka mengakses internet untuk mencari informasi melalui Google search, Web atau Line (line today). Penggunaan media digital untuk mencari informasi yang dibutuhkan mencakup berbagai kepentingan yaitu untuk informasi tentang pendidikan, keagamaan, dan ekonomi atau bisnis. Untuk informasi atau seputar isu politik walaupun terdapat yang secara langsung mengatakan tidak tertarik dan juga hampir tidak pernah mencari informasi atau isu-isu terkait politik, akan tetapi terdapat pula perempuan yang 
mengaku bahwa media digital menjadi alat mereka untuk dapat mengetahui informasi politik yang selama ini kurang mereka dapatkan dari lingkungannya.

Pencarian Informasi. Penggunaan media digital untuk mencari informasi terkait pendidikan diantaranya tercermin dalam ungkapan-ungkapan berikut "Kalau internetan kadang-kadang, paling buat mencari tugas anak saja. Zaman sekarang apa saja tinggal cari di google. Kalau misalnya, dibuku pelajaran tidak ada jadi tinggal lihat saja ke google (Hasil wawancara dengan informan 4). Hal senada terkait dengan pencarian informasi juga dikemukakan oleh informan berikut "Kalo untuk internet sendiri, paling ibu suka cari artikel-artikel tentang keagamaan, pendidikan anak, pergaulan" (Hasil wawancara dengan informan 7). Berdasarkan beberapa pernyataan tersebut maka media digital memiliki peluang pula untuk meningkatkan kualitas seorang ibu dalam membantu atau mendukung pendidikan anaknya. Akan tetapi salah seorang dari informan juga menegaskan bahwa internet selain untuk berkomunikasi dengan orang lain juga digunakan untuk mencari informasi-informasi yang dapat bermanfaat bagi dirinya (Hasil wawancara dengan informan 6).

Berdasar data-data di atas terlihat bahwa kalangan perempuan juga memperhatikan dan menggunakan media digital untuk kepentingan dan kesenangannya. Sebagai perempuan mereka memiliki peluang untuk tidak saja memikirkan anggota keluarga lainnya akan tetapi melalui media digital mereka juga dapat membangun kesadaran dirinya sebagai seorang individu. Temuan ini cukup penting jika merujuk pada kajian tentang perempuan terkait dengan budaya patriarki yang umumnya mengkostruksi perempuan lebih berorientasi untuk kepentingan orang lain baik orang tua dan saudaranya saat sebelum menikah atau suami dan anaknya setelah mereka menikah. Teknologi dalam hal ini media digital memberi ruang bagi perempuan untuk mengembangkan dirinya sebagai perempuan (Saputra, 2001).

Fenomena terkait dengan media digital dan perempuan cukup menarik ketika perempuan merasa punya kesempatan untuk memilih dan memutuskan untuk mendapatkan sesuatu yang dia inginkan dan butuhkan bahkan sesuatu yang berasal dari luar lingkungan domestiknya. Walaupun secara umum mereka juga mengungkapkan bahwa mereka menjadikan urusan di rumah termasuk menjadi tanggung jawab mereka, akan tetapi saat waktu luang mereka memanfaatkan waktu yang mereka miliki untuk mencari hiburan, mencari informasi yang menambah wawasan mereka dalam berbagai aspek baik agama, pendidikan, dan yang terkait dengan aktivitas ekonomi atau bisnis.

Aktivitas Bisnis. Penggunaan media digital untuk kepentingan aktivitas ekonomi seperti jual beli dan juga transaksi keuangan melalui internet banking juga sudah dilakukan oleh beberapa informan. Untuk kepentingan aktivitas ekonomi atau bisnis yang dijalaninya seorang informan mengatakan bahwa dia juga mengandalkan informasi media digital tentang perkembangan di bidang ekonomi:

"kenaikan harga BBM, harga bahan pokok ataupun listrik, yang otomatis akan merubah segalanya akan jadi 
naik pula. Misalnya saja kenaikan tarif listrik yang bisa mempengaruhi harga per kilo dari jasa laundry yang ibu jalani karena kan bisa menghabiskan daya listrik cukup besar pada mesin cucinya"( wawancara dengan informan 5)

Media digital menjadi alat untuk melakukan komunikasi dengan teman kerja atau rekan usaha mereka. Melalui media digital jangkauan perempuan ini juga diperluas seperti diungkapkan seorang ibu yang menyatakan bahwa untuk keperluan bisnis, ibu tersebut telah tergabung dalam grup bisnis Black Walet Indonesia (Hasil wawancara dengan informan 4). Black Walet adalah sebuah bisnis network marketing atau multi level marketing. Mereka tidak saja menjual; produk akan tetapi juga merekrut pembeli untuk menjadi agen penjualan produknya. Penjelasan terkait bisnis Black Walet di peroleh dalam situs mereka berisi penjelasdan berikut ;

Bisnis Blackwalet adalah sebuah Bisnis Network Marketing atau Multi Level Marketing yang sudah legal, diakui oleh Negara Republik Indonesia, buatan anak negri sendiri milik PT. Raja Walet Indonesia. Sudah mendapatkan penghargaan bisnis sejak tahun 2017 sampai saat ini. BlackWalet menyediakan produk utama untuk kesehatan kulit dan kecantikan berbahan herbal dengan kualitas premium. Pemasarannya dilakukan dengan cara network atau mengembangkan keagenan sehingga diharapkan bisa memberikan manfaat bagi banyak orang (https://daftarblackwalets.blogspot.c om/)

Selanjutnya di dalam situsnya mereka menjelaskan bagaimana caranya agar khalayak pengaksesnya dapat terlibat dalam bisnis multi level marketing yang mereka kelola. Untuk terlibat paling tidak kita harus membayar pendaftaran sebesar Rp. 20.000,- dan membeli produk mereka sebesar Rp. 260.000,-. Artinya para perempuan yang terbujuk oleh tawaran Black Wallet karena alasan ingin menambah penghasilan, pertama-tama justru menjadi pembeli produk yang sebenernya tidak terlalu mereka butuhkan.

Selain itu dalam situsnya Black wallet juga menyampaikan beberapa hal menarik bagi orang-orang yang mau terlibat dalam bisnis mereka yaitu dengan kalimat-kalimat berikut :

1. Anda BUTUH Penghasilan TAMBAHAN!

2. Anda tidak ingin SEUMUR HIDUP Bekerja untuk orang lain.

3. Anda ingin bisa Liburan Kapanpun Anda Mau tanpa pusing mikirin cuti.

4. Anda ingin bisa Bangun Tidur Sesuka Hati.

5. Anda tidak ingin Diperintah \& Dimarahi oleh atasan yang tidak mengerti Anda.

6. Anda merasa pekerjaan sekarang Tidak Sepadan Dengan Hasilnya.

7. Anda ingin Lebih Banyak Waktu untuk orang-orang yang anda sayangi.

8. Anda Tidak Ingin Meninggalkan Keluarga saat bekerja/ berbisnis

9. Capek bermacet ria \& habiskan waktu di jalan tiap hari.

10. Anda sadar sebagai karyawan Tidak Ada Jaminan sampai kapan perusahaan butuh anda

11. Anda ingin bisnis yang pada akhirnya bisa hasilkan profit terus menerus meskipun sedang bersantai

12. Anda ingin bisnis yang Bisa Diwariskan ke orang yang anda sayangi (bukannya mewariskan hutang). 
13. Anda ingin segera mempersiapkan

HARI TUA anda dari sekarang (pensiun dini \& menikmati hidup) dengan membangun "kerajaan bisnis" bagi keluarga anda!

Ini menjadi salah satu tantangan bagi para perempuan untuk dapat menyikapi beragam tawaran dari media online untuk terlibat dalam bisnis multi marketing. Salah seorang tokoh masyarakat di Jatinangor mengatakan bahwa " ibu-ibu disini sekarang memang sudah banyak yang punya handphone jadi sudah banyak tahu macem-macem dari internet. Tapi ya kadang kan dia juga harus hati-hati jangan sampai kena tipu. Itu paling yang saya khawatirkan, maklum aja perempuan kan suka gampang dibujuk".

Salah seorang peneliti media medos digital mengatakan bahwa 'terkait dengan bisnis online baik yang langsung maupun dengsan sistem multi level marketing belum banyak aturannya atasu bahkan secara khusus belum ada. Ini menjadi peluang terjadinya penipuan yang dapat menimbulkan korban yang cukup luas kartena jangkauan media digital juga kan sangat luas dan tidak terbatas oleh jarak. Walaupun dapat dikatakan juga digital marketing memberi peluang besar untuk berkembang dan menarik banyak orang untuk terlibat dalam bisnis online atau merintis kerjasaam bisnis berdasarkan interaksi di online. Salah seorang akademisi yang malakukan banyak riset tentang regulasi komunikasi dan media mengungkapkan bahwa lambatnya kemampuan regulasi untuk mengeluarkan peraturan yang dibutuhkan dalam berbagasi aktivitas digital marketing mendorong munculnya peraturan yang dihasilkan komunitas di bidang tersebut. Melihat fenomena tersebut beliau menyatakan bahwa 'hal itu buat saya menarik, karena membuktikan masyarakat kemudian mampu membuat aturan agar praktis bisnis mereka berjalan baik atau seperti yang mereka harapkan".

Hiburan. Penggunaan media digital untuk hiburan selain menjalin perbincangan tentang beragam isu termasuk hal-hal yang menghibur di dalam group-group media sosial seperti WhatsApp, media sosial You Tube juga umum digunakan untuk menonton, video streaming baik untuk menonton film-film yang awalnya diputar di bioskop, menonton program televisi yang disukai seperti sinetron, atau untuk radio streaming dan mendengarkan musik. Berbagai hiburan yang tidak memerlukan aktivitas fisik menjadi pilihan banyak pengguna media digital. Menggunakan media digital untuk mendapatkan hiburan menjadi pola aktivitas banyak orang termasuk perempuan pengguna media digital di Jatinangor. Aktivitas untuk mencari hiburan juga terkait dengan penggunaan waktu luang seseorang mereka baik di siang hariu atau di amalam hari ketyika akan. tidut. Pola pemanfaatan media digital oleh perempuan di Jatinangor tidak terlalu berbeda dengan kalangan perempuan perkotaan. Hal ini diungkapkan oleh salah seorang pengamat media digital. Menurut beliau karakteristik media digital yang bersifat virtual menempatkan para pengguna dalam dunia virtual yang terlepas cdari dunia nyata penggunanya. Oleh karena itu karakteristik sosial budaya seorang pengguna dapat terabaikan saat mereka terlibat dalam aktivitas di dunia virtual. Hal tersebut juga ditemukan dalam sebuah penelitian yang melihat penggunaan waktu luang di kalangan remaja pedesaan dan perkotaan 
tidak memperlihatkan perbedaan. Kedua kelompok remaja lebih banyak menikmati hiburan yang tidak melibatkan aktivitas fisik akan tetapi aktivitas menetap yaitu menggunakan media digital -games(Sjolie, 2002).

Terjadinya konvergensi teknologi memberi peluang perempuan untuk menikmati hiburan dari media konvensional televisi melalui media digital. Hal ini memberi ruang bagi perempuan yang selama ini memiliki keterbatasan waktu baik sebagai ibu rumah tangga atau ibu-ibu yang bekerja sekaligus juga sebagai ibu rumah tangga. Kesulitan mereka untuk secara rutin dan konsisten dalam waktu untuk dapat mengakses hiburan dari media televisi teratasi dengan adanya media digital. Melalui media digital mereka dapat menyesuaikan waktu menonton mereka dengan waktu yang mereka miliki seperti dinyatakan oleh salah seorang informan berikut :

"Sekarang kan kita bisa lihat film atau sinetron yang kita mau tonton kapan aja kita punya waktu, pokokna lebih bebas waktunya maklum kita mah perempuan kalau nonton juga suka sambal kerja atau diganggu urusan rumah" (Hasil wawancara dengan informan 5).

Berdasarkan beberapa gambaran di atas maka dapat dikatakan bahwa penggunaan media digital digunakan perempuan untuk meningkatkan kualitas perannya sebagai seorang ibu maupun kualitas komunikasi dengan keluarganya baik suami maupun anak mereka. Selain itu media sosial menjadi aplikasi yang sangat membantu mereka untuk mengembangkan pergaulan mereka melalui beragam group sosial media serta beragam informasi yang mereka butuhkan, atau dapat memperluas wawasan mereka terkait dengan informasi pendidikan, agama, ekonomi dan politik. Salah seorang tokoh masyarakat menyatakan bahwa saat ini kalangan perempuan di daerah Jatinangor sudah semakin pintar dalam mengakses internet melalui smartphone mereka. Mereka juga memanfaatkannya untuk berbagai kepentingan termasuk untuk urusan belanja atau kepentingan dagang atau usaha mereka.

Penggunaan media digital ini juga diakui beberapa informan dilakukan dengan sangat intens seperti jawabanjawaban 'sering banget, 'ya 24 jam' atau penggunaan media baru sampai saat akan tidur seperti yang diungkapkan salah seorang informan berikut yang menyatakan bahwa "Ibu sih sering liat You Tube, sebelum tidur streaming video (Hasil wawancara dengan informan 5). Di sisi lain penggunaan media digital juga dapat memunculkan kebiasaan baru terutama saat akan tidur. Merujuk pada pernyataan tersebut maka dapat dikatakan bahwa kesempatan perempuan pengguna media digital untuk mendapatkan hiburan meningkat akan tetapi juga dapat mengganggu waktu istirahat mereka, terutama saat akan tidur. Intensitas beberapa pengguna media digital di Jatinangor juga sudah sangat tinggi. Artinya mereka sudah memiliki tingkat ketergantungan yang sangat tinggi. Merujuk pada fenomena tersebuti menurut salah seorang pengamat media walaupun kontek sosial budaya berperan terkait dengan efek media pada anggotanya akan tetapi tingkat ketergantungan seseorang pada media juga akan memengaruhi dampak media tersebut pada penggunanya. Sejalan yang diasumsikan oleh teori ketergantungan media salah satu riset menyatakan bahwa media pada akhirnya 
memiliki kontrol pada individu (Maxian, 2014), dalam riset ini kontrol juga terjadi dalam penggunaan waktu luang atau istirahat para perempuan pengguna media digital di Jatinangor.

Aktivitas penggunaan media digital yang cukup tinggi dikhawatirkan mengganggun kesehatan psikologis penggunanya seperti yang ditunjukan salah satu riset terhadap penggunaan media sosial di kalangan remaja. Berdasarkan penelitian tersebut ditemukan bukti tentang pengaruh penggunaan media sosial pada depresi, kecemasan dan tekanan psikologis pada remaja. Pencarian database PsycINFO, Medline, Embase, CINAHL dan SSCI menuai 13 studi yang memenuhi syarat, 12 di antaranya merupakan cross-sectional. Temuan diklasifikasikan ke dalam empat domain media sosial: waktu yang dihabiskan, aktivitas, investasi dan kecanduan. Semua domain berkorelasi dengan depresi, kecemasan, dan tekanan psikologis (Keles, 2019).

Salah seorang informan juga mengaitkan penggunaan telepon seluler sebagai media baru merupakan kebutuhan yang berkembang sejalan dengan perubahan sosial yang terjadi di masyarakat saat ini. Hal seperti itu terungkap dalam pernyataan salah seorang ibu yang mengatakan bahwa "jaman sekarang kan jamannya handphone (Hasil wawancara dengan infroman 8)". Artinya dalam persepsi informan tersebut penggunaan handphone merupakan hal yang sudah menjadi sesuatu yang seharusnya memang dilakukan masyarakat sekarang. Sejalan dengan apa yang ditegaskan dengan catatan Ball-Rokeach's tentang kekuasaan media. Individu membutuhkan media untuk berfungsi di masayarakat modern dan memiliki ketergantungan pada media (Maxian, 2014). Selain itu terkait dengan perkembangan jaman masalah perkembangan gaya berpakaian atau fashion juga menjadi salah satu perhatian informan seperti pengakuan informan yang kerap mengunjungi web site merek pakaian tertentu. Merujuk pada beberapa pernyataan di atas maka akses perempuan ke media digital juga memiliki tantangan bagi perempuan untuk mampu bersifat selektif terhadap berbagai informasi yang menerpa mereka atau mereka akses. Apabila mereka tidak selektif dan tidak terbiasa mempertimbangkan berbagai keputusan secara lebih rasional bukan emosional maka mereka menjadi rentan menjadi objek dari berbagai informasi yang menjadikan mereka sekadar pasar atau pengikut dari segala hal yang ditawarkan.

\section{SIMPULAN}

Penelitian ini menyimpulkan bahwa penggunaan media digital di kalangan perempuan memperlihatkan beberapa peluang sekaligus tantangan bagi perempuan. Berdasarkan analisis data diperoleh hal-hal yang menarik terkait dengan peluang yang diperoleh perempuan di Jatinangor terkait dengan penggunaan media digital yang mereka lakukan. Pertama, perempuan yang mampu menggunakan media digital mendapat ruang komunikasi yang lebih luas bahkan sangat luas dibandingkan yang secara alamiah dapat diberikan oleh lingkungan atau budaya mereka. Para pengguna media digital memiliki kesempatan untuk melakukan interaksi dan komunikasi dengan berbagai pihak di luar lingkungannya serta diterpa atau 
mengakses isu-isu publik yang selama ini jarang menerpa mereka.

Penggunaan media digital memberi peluang mereka untuk mengatasi hambatan budaya yang mereka miliki dalam proses komunikasi mereka dengan dunia luar dan juga berbagai kepentingan. Kedua, melalui penggunaan media digital dengan berbagai aplikasinya juga dapat membangun kesadaran para perempuan terhadap kebutuhannya sebagai individu khususnya individu perempuan berdasarkan pemikiran dan pilihan mereka. Upaya membentuk kesadaran diri tidak terbatasi oleh nilai-nilai yang umumnya ditanamkan pada perempuan khususnya di daerah Jatinangor dalam konteks budaya Sunda yang sarat nilai-nilai patriarki dan menempatkan perempuan sebagai bagian atau subordinat dari orang tua, saudara laki-laki maupun pasangan hidupnya.

Implikasi dari penggunaan media digital oleh kalangan perempuan di Jatinangor selain adanya peluang yang dapat memberdayakan perempuan di Jatinangor, akan tetapi juga memiliki tantangan terkait dengan kesiapan mereka untuk berinteraksi dengan berbagai sumber informasi dengan beragam kepentingan yang menjadikan kalangan perempuan hanya sebagai sasaran atau objek kepentingan mereka. Selain itu mereka juga menjadi rentan dari kejahatan di dunia syber atau digital juga karena beberapa hal. Pertama para pengguna tidak terlalu memahami pentingnya melindungi data privacy sehingga seringkali menggunggah atau memposting konten baik teks atau gambar yang diperuntukan untuk public tanpa batasan. Kedua keinginan kaum perempuan untuk menambah penghassilan keluarga sering terjadi dan ini juga terjadi pada para perempuan pengguna media digital di Jatinangor. Melalui media digital mereka terlibat dalam bisnis online diantaranya dalam jaringan multi level marketing. Akan tetapi dikarenakan mereka kurang memahami bagaimana menjalankan bisnis online atau salah satunya yang berbentuk multi level marketing akhirnya mereka hanya jadi konsumen. Dengan kata lain tanpa kemampuan mendalami atau menyeleksi informasi dan berbagai tawaran yang diperoleh dari media digital juga menjadikan mereka rentan dimanipulasi sehingga alih-alih dapat meningkatkan pendapatan yang terjadi adalah meningkatkan pengeluaran mereka untuk berbelanja barang-barang yang tidak terlalu mereka butuhkan atau bersifat konsumtif.

Berdasarkan simpulan yang diperoleh maka pada akhirnya penelitian ini merekomendasikan perlunya literasi digital khusus untuk kalangan perempuan media digital. Beberapa temuan penelitin ini dapat dijadikan dasar untuk mengembangkan literasi digital di kalangan perempuan sekaligus juga memberi masukan untuk perbaikan terkait kebijakan di bidang digital. Melalui literasi digital dan kebijakan digital yang peka gender maka diharapkan pengguna media digital perempuan dapat lebih diberdayakan dan dilindungi khususnya kalangan perempuan di daerah-daerah transisi seperti Jatinangor.

\section{UCAPAN TERIMA KASIH}

Kami mengucapkan terima kasih kepada Fakultas Ilmu Komunikasi dan Universitas Padjadjaran yang mendukung terlaksananya penelitian mandiri ini sehingga dapat menjadi sumber data penulisan artikel ini. Walaupun penelitian 
ini tidak membutuhkan dana yang relatif besar akan tetapi dukungan pihak Fakultas terhadap kegiatan penelitian ini sangat membantu terselesaikannya penelitian ini. Kami juga mengucapkan terima kasih kepada mahasiswa yang terlibat dalam kegiatan diskusi, pengumpualan data lapangan maupun mempersiapkan transkrip hasil wawancara untuk kepentingan analisis data.

\section{DAFTAR PUSTAKA}

Cresswell, J. W. (2007). Research Design: Qualitative \& Quantitative Approaches. New York: Sage Publications.

Fakih, M. (2016). Analisi Gender dan Transformasi Sosial. Yogyakarta: INSIST Press.

Gan, J. (2017). Gender Inequalities in the Prevalence, Perception, and Reporting of Cyberstalking in Malaysian University Students. International Journal of Gender \& Women's Studies, 5(2). https://doi.org/10.15640/ ijgws.v5n2a1

Keles, B., McCrae, N., \& Grealish, A. (2019). A systematic review: the influence of social media on depression, anxiety and psychological distress in adolescents. International Journal of Adolescence and Youth, 115. doi:10.1080/02673843.2019.1590 851

Khadijah, S., (2018). Bullying and Verbal -Nonverbal Communication Among A Group College Student, Jurnal Avant Garde, Vol 6, No. 1, 2018, Jakarta, Universitas Budiluhur, DOI: http:// dx.doi.org/10.36080/avg.v6i1.749

Kominfo. (2017). Penggunaan TIK (Teknoogi Informasi dan
Komunikasi) serta Implikasinya terhadap Aspek Sosial Budaya Masyarakat. Jakarta: Badan Penelitian dan Pengembangan SDM.

Malikhao, P. (2014). Intercultural Communication for development in Budhis Perspective, dalam Savaes J. (ed) Technological Determinism and Social Change. London: Lexitons Book

Maple, C. (2017). Security and privacy in the internet of things. Journal of Cyber Policy, 2(2), 155-184. https://doi.org/10.1080/23738871.201 7.1366536

Maryani, E., \& Astari, S. (2019). Selebriti dalam Digital Activism Tentang KekerasanTerhadap Perempuan di YouTube. Jurnal Manajemen Komunikasi, $\quad 3(1), \quad 1$. https://doi.org/10.24198/jmk.v3i1.206 56

Maryani .E \& Zuriyyatina (2018). Vol5, No 4 (2018) Advokasi Keterlibatan Laki-laki dalam Pemberian ASI, Prodi Ilmu Komunikasi, Universitas Riau

Maxian, W. (2014). Power to the People? Emotional Components of Media Power, Mobile ICTs and Their Potential to Alter Individual-Media Dependency Relations. Mass Communication and Society, 17(2), 274-298.

https://doi.org/10.1080/15205436.201 3.830133

Milles, M.B. and Huberman, M.A. (1984). Qualitative Data Analysis.

London: Sage Publication

Mulyana, D. (2018). Metodologi Penelitian Kualitatif, Paradigma Baru Ilmu Komunikasi dan Ilmu-Ilmu Sosial lainnya. Bandung: Rosdakarya. Pemerintah Provinsi Jawa Barat. (2018). 
Bandung Selatan Masuk Megapolitas

Urban Area. Retrieved from https://jabarprov.go.id/index.php/new s/28585/2018/06/23/Bandung-

Selatan-Masuk-Megapolitan - UrbanArea

Perdana, P. P. (2019). Kota Bandung Akan Diperbesar Jadi Metropolitan Bandung Raya. Kompas. Retrieved from

https://surabaya.kompas.com/read/20 19/04/26/20031711/kota-bandungakan-diperbesar-jadi-metropolitanbandung-raya.

Rahmawan D. (2018) E3S Web Conf. Volume 73, 2018, The $3^{\text {rd }}$ International Conference on Energy, Environmental and Information System (ICENIS 2018) https://:doi.org/10.501/e3scon/ 20187311014
Salter, A., \& Blodgett, B. (2012). Hypermasculinity \&amp; Dickwolves: The Contentious Role of Women in the New Gaming Public. Journal of Broadcasting \& Electronic Media, 56(3), 401-416. https://doi.org/ $\quad 10.1080$ /08838151.2012.705199

Saputra, D. (2001). Single White E-Mail, Fenomena Perempuan Abad Milenium. Jurnal Perempuan, 18, 23-29.

Sjolie, A. N. (2002). School journeys and leisure activities in rural and urban adolescents in Norway. Health Promotion International, 17(1), 2130. doi:10.1093/heapro/17.1.21 